\begin{tabular}{ccc}
\hline ManAGEMENT ISSUES IN & INDUSTRIAL \\
HEALTHCARE SYSTEM & MANAGEMENT \\
\hline
\end{tabular}

\title{
Factors for determining quality perceptions in hospitals: An assessment in terms of doctors and nurses
}

\author{
Ayse Gozde KOYUNCU*, Baris KOYUNCU \\ Faculty of Economics and Administrative Sciences, Near East University
}

\begin{tabular}{ll}
\hline & ABSTRACT \\
\cline { 2 - 2 } $\begin{array}{l}\text { Keywords: } \\
\begin{array}{l}\text { Hospital, Service } \\
\text { Quality, Perception of } \\
\text { the Quality, Private }\end{array} \\
\begin{array}{l}\text { Hospital, Public } \\
\text { Hospital, Doctors and }\end{array}\end{array} \quad \begin{array}{l}\text { Quality in health care services is the fulfillment of the expectations and needs of the customers } \\
\text { in all service processes as well as diagnosis, treatment, and care services in accordance with } \\
\text { the standards of internationally valid indicators. For this reason, it has become a necessity to } \\
\text { put some efforts into delivering high quality service. In this study, the quality perception of the } \\
\text { services offered at the hospital was evaluated based on the employees (doctors and nurses) } \\
\text { who can be called as internal customers of the hospital. For this purpose, a field study was }\end{array}$ \\
$\begin{array}{l}\text { Correspondence: } \\
\text { aysegozde.koyuncu@neu.e } \\
\text { du.tr }\end{array}$ & $\begin{array}{l}\text { conducted with the participation of a total of two hundred doctors and nurses from five } \\
\text { university hospitals operating in the private and public sectors and the findings were } \\
\text { evaluated. }\end{array}$
\end{tabular}

(C)AIMI Journals

\section{Introduction}

Hospitals protecting human health and having the obligation to provide social services as well as medical services have had to cope with very complicated problems of globalisation which brings in tough and variable economic conditions. These conditions put many health institutions under pressure to use their resources in the most rational way to meet the vague performance criteria. It is no longer enough for closely following the medical knowledge and technology and solely to equip the hospital with advanced medical equipment.

Nowadays, the service quality of countries' health services is counted as one of the most important criteria that are considered to be an indication of developmental status. Technological developments, developments in diagnosis and treatments, an increase in selfawareness levels of individuals resulting in growing importance of health care change the 
perspective, increase expectation, and thus increase the importance of health care services (Uğurluoğlu \& Payziner, 2011).

Like any organization that has to reach out to clients and provide them products and services, healthcare providers need to focus on issues such as service quality and customer satisfaction: Because, as is well known, perceived service quality and customer satisfaction are very essential for both hospitals and those who benefit from hospital services. These days, healthcare institutions have to satisfy patients' medical needs as well as their emotional, aesthetic needs, and expectations: Because, the quality of the health care services is the indicator of the patient's satisfaction during the continuation and the end of the medical treatment. To express it briefly, patient satisfaction determines the quality of health care (Özen, Çam, \& Aslay, 2011).

However, considering people, who benefit from hospitals as only patients, will bring a limited perspective because the hospitals' customers are not only the patients, but also the relatives accompanying the patients, doctors, nurses and other health care employees who work for the hospital and benefit from the hospital resources. Therefore, this study tackles with the evaluations of doctors and nurses who can benefit from the services of the hospital and can be referred as internal customers.

\section{Service Quality and Service Quality Perception in Hospitals}

In the health care sector, which is one of the most important areas of the services sector, the growing importance of the costs foregrounds the concept of 'quality' with the increased expectations of those who benefit from the health care services and competition with the attitudes. The concept of quality, affecting the lives of every population, is the concept that has emerged in the direction that urges people and systems to make no mistakes and achieve perfection (Karagöz, 2010).

Health care is a broad concept that includes the physical facilities of the hospitals as well as the interaction of patients and their relatives with the health care providers (doctors, nurses, patient caregivers, etc.) (Öztürk, 2009). It is clear that patient satisfaction is the determinant that will make a difference in terms of health care providers;so that patients and their relatives evaluate the offered services and alternative facilities better and prefer an institution which meets their expectations best. However, this preference is not clearly differentiated between private hospitals and public hospitals; because, beyond personal choices, the financial capabilities also have influence on this preference.

In terms of health, it may be possible to define the concept of quality as a degree of conformity with recognized scientific standards (Gürsoy, 2013). However, another important issue that should not be overlooked is the social and psychological demands, expectations, and needs of patients and their relatives. As already mentioned, there are significant differences in the individuals' preferences of the hospitals, ability to access to and the utilization of the health care services. Therefore, in order to evaluate the quality of the health care service provided, it is necessary to analyze the factors causing these differences (Karaca, 2006).

According to Kavuncubaş1 (2000), the quality of health care services is formulated as follows: 


\section{Quality of Health Care Service = Technical Quality + The Art of Medical Treatment}

According to this Technical Quality is defined as the accordance of the diagnosis and treatment services with contemporary medical science, scientific standards and norms, and the Therapeutic Art is expressed (Kavuncubaş1, 2000) as the provided services meeting the level of expectations of the patients and their relatives, i.e Perception of Quality.

In the current competitive environment, companies' dependence on their assets to survive and succeed is based on increasing the quality, reducing the costs, and keeping customer satisfaction in the forefront: to this end, Total Quality Management system provides these aspects of quality (Güngör, 2008).

The Total Quality Management definition is the patient happiness in terms of health sector. The right diagnosis, treatment, undelayed, good-humoured service, clean and comfortable environment, and reasonable costs are the factors constituting the elements of total quality in providing the happiness of the patient and patient's relatives. For all that, happy and healthy staff working in appropriate conditions are also among these targets. In other words, total quality management in hospitals is aimed to be performed within the framework of the happiness of hospital employees and patients (Morgil \& Küçükçirkin, 1996).

For this reason, in order to increase the quality of the service offered at the hospital, it is inevitable to ensure clear, understandable, and all-inclusive quality standards, more rigorous selection of staff who are able to carry out the aims determined by the organisation, and to increase the motivation of the employees to improve the quality (Işık,2005) At the same time, upon evaluation from the point of patients and their companions, it is considered that improving the physical facilities of the hospital and increasing the comfort provided during the hospital stay will significantly affect the perception of the provided service quality.

However, it is possible to evaluate service quality under two titles, namely expected service quality and perceived service quality (Özatkan, 2008). Expected service quality is used to describe the expectations of the individuals about the service and the characteristics of the product or service to satisfy the individuals. However, the perceived service quality is expressed as the degree and direction of the difference between the expectations from the service and the actual service (Parasuraman, Zeithaml, \& Berry, 1988). In the perceived quality, it is considered that not the quality of goods or services, but the provided benefits of the goods or services to the customers as a whole is important (Canpolat, 2002).

In general, to determine the quality of service, some aspects such as physical factors, reliability, correct and on-time service, and mutual communication gain importance (Parasuraman et al., 1988). When hospitals are taken into consideration, it can be said that physicians and nurses play an important role besides the physical factors; because as mentioned before, quality increases with the interactions of the patients, doctors, and nurses. Perceived service quality will vary from individual to individual since many factors such as the priorities, values, level of education, culture, age or gender of the individuals shape the individuals' expectations. In other words, individuals' expectations of service quality affect perceptions of the service quality. 
Quality perception is accepted as one of the most important criteria that can be used in the evaluation of medical and social services. For this reason, health staff are required to take patient preferences and social expectations into account in quality assessments and developmentto ensure that the provided service is consistent with patients' wishes, values, and expectations (Serbest, 2006).

The evaluations of service quality are mostly different. Since the offered service is abstract, it also abstracts the quality of service. Therefore, considering the services offered at the hospitals, evaluating the quality of the treatment will not be as easy as evaluating the quality of the food prepared. To this end, it will require knowledge and expertise to evaluate an operation performed while personal taste is sufficient in evaluating the food served at the hospital. In that case, the distinction of evaluation of the services offered at the hospital as medical services and social services will be appropriate in terms of providing logical evaluations for this study as well.

Hospitals are accepted as the milestones of the health care system because they provide the most important role in public health services (Yazgan, 2009). In this context, just beyond being a place to provide medical services, they can be influenced by many individual and environmental factors such as welfare level, consumption behavior, educational status of individuals, cultural level, health system structure and function, and health policy (Gürsoy, 2013). Although all hospitals offer the same type of service, they choose to differ in their services from their competitors due to the ingravescent competition conditions. For instance they have to work hard to improve service quality and to achieve excellence in the service and no-mistake target (Zaim \& Tarım, 2010).

\section{Method}

Evaluation of the quality perceptions of the doctors and nurses, working in the hospitals, about medical and social services constitutes one of the primary objectives of the study. For this purpose, within the context of this study, the data were collected from medical doctors and nurses (200 persons) working in five different hospitals (public sector / private sector).

Two hundred subjects as doctors and nurses working in two private universities (Ufuk University Ridvan Ege Hospital and Baskent University Hospital) and three public university hospitals (Hacettepe University Medical Faculty, Ankara University Ibn-i Sina Hospital and Gazi University Hospital) in Ankara have been involved in the study.

The median age of all subjects who participated in the study was 33.92 years. The median age for women was 33.23 years $(\mathrm{SD}=8.50)$ while the median age for men was 35.29 years $(\mathrm{SD} .=8.54)$.

In terms of the findings obtained in this study, the most important variant was the difference between the public hospital and the private hospital. According to this, most of the nurses participating in the study (70 people) were working in the private hospital. In terms of medical doctors the case was opposite and more than half (49 people) of the medical doctors participating in the study were employed in public hospitals.

The majority of nurses participating in the study (61 people) were working in Baskent University Hospital. The vast majority of medical doctors (47 people) who participated in the study was working in İbn-I Sina Hospital of Ankara University. It is satisfactory in terms of 
comparability of research findings that one of the two leading hospitals belongs to the public sector and the other belongs to the private sector.

Looking at the duration of work in the institutions where the participants were involved, $60.2 \%$ of physicians and $53 \%$ of nurses stated this period as one to five years. This finding was followed by nurses who worked between six and ten years $(19.7 \%)$ and doctors who worked longer than fifteen years $(9.6 \%)$.

The last item to be mentioned about the participants was the areas of expertise. The vast majority of participants' area of expertise was stated as general surgery. On the other hand, radiology, infectious diseases, pediatrics, and physical therapy and rehabilitation were the areas with the least participation.

Based on the aim of study, a sociometric questionnaire was developed to determine the participants' demographic characteristics and the physical and social conditions of the hospital and the quality perceptions of the participants.

The data were collected from doctors and nurses working at five university hospitals in the province of Ankara (Ankara University Ibn-i Sina Hospital, Gazi University Hospital, Hacettepe University Hospital, Başkent University Hospital, and Ufuk University Hospital). This research was conducted in university hospitals in Ankara because it was thought that it would provide a more statistically meaningful comparison. Participants were asked to answer the questions in the questionnaire. The practice was carried out individually and reached 200 participants.

\section{Results}

\section{Findings from the Question Group on Quality of Hospital Services}

The subjects who participated in the research were divided into two groups in terms of their work in public and private sectors. The frequency and percentages of the perceptions of the quality of hospital services were separately calculated for medical doctors and nurses in each group. According to this, the medical service quality offered at the hospital was considered good (sufficient) for the vast majority of the medical doctors $(59.2 \%)$ and nurses $(53.2 \%)$ working in the public sector as well as the medical doctors $(76.5 \%)$ and nurses $(64.3 \%)$ working in private hospitals.

However, the same satisfaction was not achieved in terms of social services offered at the hospital. Following this, $41.2 \%$ of the doctors and $42.9 \%$ of the nurses working in the private sector were satisfied with the offered social services whereas this ratio was lower $(38.8 \%$ and $36.2 \%$ ) in the medical doctors and nurses working in the public sector. However, the ratio of those who believed it was inadequate was between $20 \%$ and $30 \%$ for both medical doctors and nurses and this was a substantial level. In this context, in terms of medical doctors and nurses working in public as well as private sectors, it was considered that the offered social services in the hospitals were not adequate.

When medical doctors were asked for their evaluations of the last five-year period, a significant number of private $(47.1 \%)$, as well as the public sector $(40.8 \%)$, indicated improvement in the quality of medical services provided in their hospitals. However, when medical doctors' evaluations for the offered social services were examined, it was found that there was not a significant difference between private and public sector. 
When the same question was evaluated by nurses, it was concluded that there were not any changes in the offered services (medical and social) in the public and private hospitals. With regards to the service providers for hospitals, most of the doctors working in public hospitals $(73.5 \%)$ and nurses $(80.9 \%)$ stated that meals were cooked in the hospital but for private hospitals, thisrate was calculated as $58.8 \%$ for doctors and $37.1 \%$ for nurses. However, the presence of substantial proportion of the opposite responders rises the question about the insufficient amount of knowledge about the subject they have. Similarly, the lack of clear answers to questions about cleaning and computing services (both public and private) showed that employees were not sufficiently informed in terms of management. This may be considered as a shortcoming of the hospital management, as well as the lack of interest in the administrative issues of the individuals.

\section{Findings from Question Group on Quality of Service Providers in Hospitals}

In this section, the four most important components, namely "the expertise of doctors and nurses", "easy transportation to the hospital", "care and recovery of the patients", and "the approach of doctors and nurses to the patients" were evaluated in terms of the quality of the services provided in the hospitals and the interests of the participants to these elements. When evaluated by nurses, "patient care", "expertise of doctors and nurses", "the approach of the doctors and nurses to the patient" were the foregrounds and "easy transportation to the hospital" was also found as important factor for nurses working in private hospitals. Therefore, it can be said that the medical factors were the most important determinants of service quality in terms of doctors and nurses working in private and public sectors.

Among the doctors and nurses who participated in the research, the nurses who were working in private hospitals mostly believed that there was a difference in the service quality in private and public hospitals. In general, about $60 \%$ of all doctors and nurses believed that there was a difference in various levels in private and public hospitals. Still, $10 \%$ of doctors and nurses believed that there was not any difference.

According to the doctors and nurses, the most important factors that make a difference in terms of quality of medical service for doctors working in private hospitals were service cost, equipment, technology, and the number of patients. For doctors working in public hospitals, "waiting periods for examination results", "the number of patients", and "technology" were listed as the primary differences in quality of medical service.

When considering the evaluations of nurses, "number of staff", "personal care and attention offered to the patient", and "staff experience" were considered as the primary differences in terms of nurses working in private hospitals. For nurses working in public hospitals, it was seen that "the number of staff", "technology", and "the number of patients" were on the foreground.

According to the medical doctors and nurses working in private hospitals, the most important factors that made a difference in the quality of social services were "personal care", "sufficient number of staff", and "the number of patients". Nevertheless, it was seen that the "staff experience" was also regarded as very important item by nurses. This can be explained by the social contact of patients and nurses. 
In terms of doctors working in the public sector, "personal care", "service cost", "catering services", and "the number of patients" were more important factors determining social service quality. For the nurses working in the public sector, "the number of patients", "personal care", and "sufficient number of staff" factors appeared to be the foreground.

By the nurses, the most important determinants of the difference between the two sectors in terms of the quality of the offered medical service between private and public hospitals were reported as "the doctors and the nurses" and even especially the nurses. This result was compatible with the level of knowledge and skill of the doctors and nurses that was counted as important in the previous section. In addition, in terms of participants, it was expected that those who make a difference in service quality should be the doctors and nurses since they are in contact with patients and their relatives.

However, both the public and private sector doctors considered themselves as the more important factors, while the proportion of those who believed that it was the influence of the members of the board of directors and hospital administrators was not negligible (\%30-40). Physicians and nurses working in public as well as private hospitals were largely pointed out the members of the board of directors and managers as the determinants of the social service quality that makes a difference. This situation put more emphasis on the difference of social aspects of hospital management. However, nurses working in the private sector tended to see doctors and nurses as important factors in social services as well as in medical services.

Finally, there was no significant difference between private and public hospitals due to the answers provided by doctors and nurses regarding the services provided to patients and their companions. Although the offered social services in both groups of university hospitals were similar, the fact that there were many shortcomings in the hospitals in terms of the service providers is not overlooked. Given that hospitals were evaluated by their own staff, improvements in the quality of service for patients and their relatives might be maintained depending on the hospitals' financial capabilities.

\section{Discussion and Conclusion}

Today, the primary goals of hospitals are to satisfy more patients by attracting and allowing them to choose the same hospital again. For this reason, hospitals should pay extra attention to the quality and patient satisfaction. The quality assessments used to monitor the outcomes of the health care services are usually based on medical outcomes, cost analysis, and patient satisfaction. One of these assessments, patient satisfaction, is as important as the clinical outcome, and measuring this should be one of the priorities of every health care provider (Önsuz et al., 2008).

In this context, developed countries allocate more resources to improve the quality and quantity of health services based on the importance given to the people. Following this, the qualitative and quantitative level of health services are considered as a sign of social welfare. For this reason, more attention should be given to the quality of health services to eliminate inequalities and negativities related to the health services.

The quality of service offered in hospitals is a matter that should be considered not only by hospital staff, patients, and their relatives but also by governments. The quality of health services contributes to the healthier and happier lives of the individuals; in other words, it 
contributes to the increase of the quality of life as well as contributing to the economy of the country by means of the decrease of the health care expenditures.

The present study aimed to measure the doctors' and nurses', who were working in private and public university hospitals, considering the perceptions of the quality of the hospitals' medical and social services. Therefore, in the study, questions were initially asked to measure their perceptions of the offered quality of services in the hospitals that they were working. The services provided here have been assessed separately from medical and social aspects and the offered medical services by the hospitals have been perceived adequately in terms of doctors and nurses working in the public and private sectors. However, the same satisfaction level was not achieved in terms of the evaluation of the social services offered. The percentage of doctors and nurses working in private hospitals found social services as sufficient was around forty percent, whereas this ratio was decreased in the public hospitals down to thirty percent. In fact, this was consistent with the community belief that the offered hotel services in private hospitals are of higher quality and comfort. Another reason is that the main actors of the given medical services are doctors and nurses. Participants actually evaluated themselves to a certain extent in the answers they provided and accepted that the hospital management was responsible for the quality of the offered social services.

When the participants were asked to evaluate the last five years, the results were supporting the previous findings. Moreover, almost half of doctors working in public and private hospitals believed that there has been an improvement in medical services, but they stated that there was not any change in the quality of the social services. Looking at the evaluations made by the nurses, it was seen that there has been no change in the last five years in terms of medical and social services offered both in private and in public sector. In fact, the expectations of doctors and nurses and the level of satisfaction from the current situation were affecting these evaluations. New technologies, new diagnostic and therapeutic methods, and their introduction to daily practice were the most important factors determining the quality of the medical services provided in hospitals. In this sense, the high level of satisfaction in terms of the primary users of these elements, doctors, was a positive finding.

The decrease of positive evaluation results in terms of the comfort provided to the patients and their employees can be explained by the priorities and financial capabilities of the hospital management. However, as mentioned earlier, the concept of "quality" implies that medical and social conditions should be taken together into consideration in the hospitals. At this point, it is important for the hospital management to implement the necessary regulations by taking the social expectations and needs of the employees and the patients into account.

When we look at the findings of service providers in hospitals, there was the impression that doctors and nurses working in public and private hospitals did not have clear ideas about whether services such as food, cleaning and information processing were provided by hospital staff or not. Today, organizations are competitive and structured for innovation. Among today's competitive and innovative organizations that prefer the flexible forms of organisation, there are organisations that find the use of subcontractors beneficial, and even use subcontracting services at events related to innovation (Savc1, 2011). The research carried out in the hospitals, in which this practice was common especially in terms of food and cleaning services, shows the fact that the level of awareness was very low among employees. 
Similarly, it was indicated that doctors and nurses did not have enough information on administrative issues. This situation can be regarded as a shortcoming related to hospital management and it can be also explained by the lack interest of the individuals to the administrative issues.

When the constituents of the quality of service provided in hospitals were asked, doctors working in public or private hospitals drew attention to four factors. These were the expertise of doctors and nurses, the accessibility of the hospital, the care and recovery of the patient and the approach of the doctors and nurses towards the patient. Generally speaking, it can be said that for the majority of the population, these four elements are equally important in terms of health. In fact, these elements also reveal the main purposes of hospitals. So these evaluations may be an implicit call for the expectation of human treatment as much as the medical elements, that the patient was asked to be valued as a human rather than a customer.

Another question that considered to be crucial for the study is the difference of the perception level of the participating doctors and nurses between private and public hospitals. In this sense, mostly nurses in private hospitals believed that there was a difference in the quality of service offered between public hospitals and private hospitals. Although there was no significant difference in terms of doctors, it can be said that there was a higher incidence of differences between doctors who work in private hospitals than those working in public hospitals.

In terms of doctors working in private and public hospitals, the number of patients and technological equipment was the main factors when medical elements were considered, while the doctors working in the private hospitals emphasised the service cost and the doctors in public hospitals emphasised the waiting time of examination results. When the hospital size and the number of staff are taken into consideration, it is obvious that the number of patients really make a difference. For example, it is stated that 30.000 surgeries, 443.000 outpatients and 25.000 hospitalised patients were treated in one year in one of the public hospitals, Ankara University Medical Faculty Hospital, during the research was carried out. When the similar rates in Gazi University Hospital and Hacettepe University Hospital were considered, the hospital size and the number of staff considered important.

When the nurses' results participating in the research were evaluated based on the medical factors making differences, it was seen that the number of staff has come to the foreground as a factor in public and private hospitals. However, the doctors working in public hospitals emphasised the number of patients and technology as well, while staff in private hospitals stated that staff experience and personal care and interest to the patients were the other medical factors making the difference.

When the factors making the difference in the social services were evaluated, similar to the above results, the number of patients, personal care and sufficient number of staff were in the foreground in terms of the doctors and nurses working in public hospitals, and additionally catering services and service costs were also found as effective. It was seen that the same factors were emphasized in terms of employees in private hospitals. Following this, the number of patients, the number of staff, and the personal care and attention to the patients were the important factors affecting both the medical and social quality of service. 
As noted above, the workload of public hospitals is incredibly high and the physicians who have to examine a large number of patients throughout a day can develop negative selfjudgments as feeling unworthy. However, the workload in private hospitals is relatively limited and the physical and mental satisfaction is better. Another factor to be addressed in this regard is the physical equipment of the hospital. Private hospitals are designed just like a "guest house" and offer more satisfying working conditions to their employees. Therefore, the working environment and opportunities provided a clear picture of the difference between participants of public and private hospitals. Of course, as the number of patients decreases, the quality of the care provided to the patients will also increase.

However, the fact that the hospitals, where the research has been done, were university hospitals eliminates the difference that can arise between doctors in terms of success and performance. Because the success and performance of doctors working in university hospitals are evaluated at the degree of having academic titles, besides the patient intensity and treatment possibilities.

Responses given to the question for which the contribution of the actors in the hospital to the offered quality of service should be assessed, all participants expressed their beliefs that doctors and nurses play an important role in terms of medical services. In the previous sections, when talking about the concept of quality in hospitals, it was stated that the quality of the doctors and the nurses came up when they contact with the patient. In this context, it is not surprising that doctors and nurses were considered as the most important actors when it came to the offered quality of the medical service.

On the other hand, doctors and nurses working in public hospitals stated that hospital management had a bigger role in the social services. When this situation was evaluated in terms of the financial capabilities of the universities, it can be seen that there was a social difference. However, it is also important that when they evaluated the physical conditions of the hospitals they worked in, there was no difference between participants from private and public hospitals. It was as if those working in the hospitals of state universities or those working in private universities considered physical conditions as unrelated to the performance, and perhaps in this respect they were not in the anticipation of innovation, because what matters was only "the professional success". Nevertheless, when working in public hospitals, it is possible to talk about the existence of an expectation that the hospitals' social conditions are better. When it comes to social conditions, it is thought that the offered hotel services in hospitals and especially the services and care may be needed during hospitalisation of patients and their companions. As mentioned before, private hospitals were designed like a guest house and created a more comfortable treatment environment both for their employees and patients and their companions. For this reason, it is also expected that there will be a higher expectation of better social conditions in terms of the number of patients and available staff in public hospitals.

When the scores obtained from the sociometric question group, evaluating the quality of service and physical conditions of the hospitals were taken into consideration, some differences occurred in terms of doctors and nurses according to the hospital type.

To this end, doctors answered this question, Is your hospital performing cleaning services by the hospital staff?, pointing out that this service was taken from other companies in public 
hospitals. In other words, public hospitals seem to be using the subcontracting service more intensively.

Considering the perceptions of the quality of social services currently offered, the doctors working in Ankara stated that the technology used was making a difference in public and private hospitals. In other words, doctors working in public hospitals tended to see the technology used in their hospitals was more inadequate when compared to private hospitals. This can be explained by the fact that private hospitals provide more satisfying working conditions and have more economic opportunities.

When the quality of the medical service offered at the hospital was evaluated in terms of the nurses, it was seen that the nurses working in the public hospitals perceived the medical service in their hospitals as inadequate. The inadequate perception of medical services including the services provided for the treatment and recovery of the patient can be explained by the number of patients in public hospitals. The fact that the number of patients they have to deal with is higher when they think about nurses who are constantly in contact with the patients individually, causes them to devote less time and less attention to each patient. However, the intensity of work causes fatigue and reluctance in nurses. Finding medical services provided insufficient under these circumstances may in fact be regarded as a selfassessment for themselves.

In terms of the nurses, the factors that make difference in the quality of medical service were the physical conditions and cleanliness of the hospital, care and recovery of the patient, personal care and interest, level of knowledge and experience of staff. Accordingly, nurses working in private hospitals were more likely to think that physical conditions and cleanliness of the hospital made a difference in terms of medical service quality. This factor, which can be considered in connection with factors such as the number of patients, hospital size, and the number of staff, also suggests outsourcing of services for similar reasons, in other words subcontracting. Previous analyses have shown that outsourcing was more common in public hospitals. In this sense, it can be said that the quality of the service is increased by the staff of the hospital.

In terms of nurses, another element which was thought to make a difference in the quality of medical service was the care and recovery of the patient. According to this, in terms of nurses working in public hospitals, it was more important to recover the patient. In general, it is the hospitals' primary purpose to provide diagnosis and treatment services. In this context, the difference between the groups (nurses working in private hospitals and nurses working in public hospitals) may be perceived as a priority for the basic services in terms of employees in public hospitals, but it may also indicate that this basic service is best provided in all conditions for nurses working in private hospitals. The previous analyses showed that private hospitals were perceived as guest houses, and care, hotel services, and comfort as well as diagnosis and treatment services were given equal importance.

At this point, in terms of nurses, another factor creating a quality of medical service difference was thought to be personal care and attention. As expected, the nurses in public hospitals believed that due to their heavy workload, the patients' personal care and patient contact were missing, and this created the negative perception on the quality of service. This finding is consistent with the results from previous analyses. 
In terms of nurses, the level of knowledge and experience of staff working in hospitals was also considered to be a factor that makes a difference between private and public hospitals' quality of medical service. It is much more common among nurses in the private sector that the level of knowledge and experience of employees will play important roles in strengthening the offered quality of the medical services at the hospital. This finding also suggests that nurses working in private hospitals consider themselves as more experienced and believe that their knowledge and experience are more important in their work.

Upon the question regarding the role played by actors in raising the quality of medical services offered at hospitals, nurses stated that the physicians were more likely to determine, and especially the nurses in private hospitals more likely to believe that doctors were doing a lot of work in this regard. In fact, this situation overlaps with the importance given to the abovementioned staff knowledge and experience.

Taken together, the results suggest that in terms of doctors and nurses working in private hospitals, the facilities offered by hospitals were perceived more positively and the working conditions were considered as more satisfactory when compared to public hospitals. The more favorable evaluations of working conditions and their hospitals strengthened their perception that they were different from public hospitals.

Considering the evaluations of the contribution of doctors and nurses to the quality of service, employees in private hospitals perceived that they had much more contributions. According to the evaluations made by both public and private hospitals, the perception that there was no significant contribution of the hospital management to the medical or social service was strongly expressed. This can be explained by the fact that doctors and nurses are in contact with patients and their relatives. In other words, because they are the ones who perform the treatment and care services themselves, they believe that they are improving the quality of the provided service. To this end, according to the doctors and nurses, the hardware and physical facilities that hospitals had and the providers of these facilities seemed to lose importance in creating quality.

This was also clearly observed from the answers given to the questionnaire designed to measure the physical facilities and equipment that hospitals already possessed. Because $n$ the answers given to the majority of the questions related to ' Do you have ... in your hospital? ', the numbers for the yes or no answers were found to be very close to each other. This situation reflects that doctors and nurses were not very interested in these services which were offered for the comfort and well-being of the patients; as if the doctors and nurses were not very concerned with the physical conditions of the hospital. A possible implication is that a higher priority was given to the medical quality than social quality, which can be wellmatched with the hospital's life-saving mission.

As a result, the main purpose of health systems is to provide high-quality health care at a higher level of efficiency, lower cost, and fairness. To achieve this goal, healthcare providers need to increase their attention to the quality concept and to take initiatives to support the adoption and diffusion of deciders' innovative ideas on the development of the health care.

\section{References}

Canpolat, C. (2002). Hizmet sektöründe kalite ve hizmet kalitesi ölçümüne yönelik bir uygulama (Unpublished master's thesis). Gazi University, Ankara. 
Güngör, J.F. (2008). Toplam kalite yönetimi ilkeleri ve hastane performansına ilişkisi üzerine bir araştırma (Unpublished master's thesis). Kadir Has University, İstanbul.

Gürsoy, A. (2013). Saglik sektorunde hizmet kalitesinin servqual olceği ile değerlendirilmesi: Bir kamu hastanesi uygulaması (Unpublished master's thesis). İstanbul University, İstanbul.

Işık, O. (2005). Hacettepe üniversitesi ihsan doğramacı çocuk hastanesi’nde çalışan doktorların hastanenin kalitesi hakkındaki değerlendirmeleri (Unpublished master's thesis).Hacettepe University, Ankara.

Karaca, N. (2006). İstanbul'da seçilen iki bölgedeki halkın sağlık hizmetlerinden yararlanma durumu (Unpublished master's thesis). Trakya University, İstanbul.

Karagöz, Y. N (2010). Sağllk Sektöründe Kalite Yönetimi Kapsamına Hizmet Kalitesinin Ölçümüne Yönelik Analitik Bir Değerlendirme (Unpublished master's thesis). Celal Bayar University, Manisa.

Kavuncubaşı, Ş. (2000). Hastane ve sağlık kurumları yönetimi. Ankara: Siyasal Kitabevi.

Morgil, O., \& Küçükçirkin, M. (1996). TOBB'un sağlıkta toplam kalite yönetimine bakışı. I. Basamak sağlık hizmetlerinde toplam kalite yönetimi sempozyumu.Ankara: Haberal Eğitim Vakfı Yayınları.

Önsüz, M. F., Topuzoğlu, A., Cöbek, U. C., Ertürk, S., Yılmaz, F., \& Birol, S. (2008). İstanbul'da bir tıp fakültesi hastanesinde yatan hastaların memnuniyet düzeyi. Marmara Üniversitesi Tip Fakültesi Dergisi, 21(1), 33-49.

Özatkan, Y. (2008). Hastane işletmelerinde hizmet kalitesinin ölçülmesi ve bir üniversite hastanesi örneği (Unpublished master's thesis). Gazi University, Ankara.

Özen, Ü., Çam, H., \& Aslay, F. (2011). Kalite boyutları ve sağlık hizmeti unsurları açısından hasta memnuniyetine bir bakış: Gümüşhane devlet hastanesi’nde örnek uygulama. Akademik Yaklaşımlar Dergisi, 1, 25-43.

Öztürk, S. A. (2009). Hizmet pazarlaması, ekin basın yayın dağıtım. Bursa: Baskı.

Parasuraman, A. , Zeithaml, V. A., \& Berry, L. L. (1985). A conceptual model of service quality and its 1mplications for future research. Journal of Marketing,49, 41-50.

Savcı, İ. (2011). Yenilik, yönetim ve insan kaynaklarl. Ankara: Siyasal Kitabevi.

Serbest, N. G. (2006). Sağlık sektöründe hizmet kalitesi ve müşteri tatmininin ölçülerek davranışlar üzerindeki etkisinin bulunmasına yönelik model çalı̧̧ması (Unpublished master's thesis). Yıldız Teknik University, İstanbul.

Uğurluoğlu, E., \& Payziner Doğanay, P.(2011). sağlık hizmetlerinde yenilikler ve yeniliklerin yayılımı”, yeniliklerin yayılımı: Kuramsal ve uygulamalı tartı̧̧alar. Derleyen: Hakkı Okan Yeloğlu, Siyasal Kitabevi, Ankara.

Yazgan, M. (2009). Sağlık işletmelerinde, hizmet kalitesinin să̆llk hizmeti sunan ve sağllk hizmeti alan taraflarca değerlendirilmesi (Unpublished master's thesis). Dokuz Eylül University, İzmir.

Zaim, H., \& Tarım, M. (2010). Hasta memnuniyeti: Kamu hastaneleri uzerine bir alan araştırması. Sosyal Siyaset Konferanslart, 59(1), 1-24. 